\title{
Differences in Returns to Education in Jordan: Gender and Public-private Sector Analysis
}

\author{
Nooh Alshyab \\ Yarmouk University \\ Serena Sandrib \\ German Jordanian University \\ Ziad Abu-Lilac \\ Al Albayt University
}

\begin{abstract}
Education is an investment and its returns in terms of increased wage can be used as an indicator for productivity in an economy. This paper analyses the relationship between education and earnings in Jordan in relation with gender and sector of employment (private versus public). Returns to education are estimated relying on a modification of the Mincer equation that takes into consideration gender and private versus public sector employment. The econometric analysis is based on the estimation of fixed effects models on a set of pseudo panel data covering the period between 2000 and 2015. The findings reveal that returns to education for male employees are higher than for female (the wage premium from one additional year of schooling is 6.8 percent for males and 5.5 percent for females) and that females get on average 74 percent of what males earn. We explain this result based on some peculiarities of female participation to the labour market in Jordan. It further emerges from the study that for male employees, wages in the private sector are 90 percent of the public sector, whereas for females, the private sector's wages are 74 percent of those in the public sector.
\end{abstract}

Keywords: gender wage differential, Jordan, public-private sector wage differential, returns to education

JEL classification: I26, J31, C33

\section{Introduction}

Human capital is widely recognised among the factors that foster economic growth and promotes economic development. Skills and education are the building blocks of human capital and reflect into economic growth (Barro, 1991) as they increase productivity

\footnotetext{
a Yarmouk University, Faculty of Economics and Administrative Sciences, P.O. Box 566, 21163 Irbid, Jordan. Email: alshyab.nooh@yu.edu.jo (Corresponding author)

b German Jordanian University, School of Management and Logistic Sciences, P.O. Box 35247, 11180 Amman, Jordan. Email: serena.sandri@gju.edu.jo

c Al Albayt University, Faculty of Finance and Business Administration, P.O. Box 130040, 25113 Mafraq, Jordan. Email: abu-lila@yu.edu.jo

Acknowledgement: We wish to acknowledge the support of the Euro Mediterranean Network for Economic Studies (EMNES).

Article Info: Received 26 October 2017; Revised 21 December 2017; Accepted 25 January 2018
} 
and, hence, wages. Thus, education is an investment for both individuals and their societies. For an individual, it should reflect, ceteris paribus, into better employability and into a higher wage.

This is the core idea underlying the huge literature trying to estimate the net benefits from education, i.e. the returns from the investment into it. Contributions have both adopted a macro and a microeconomic perspective: while macroeconomic studies have been mostly concerned with assessing the externalities of education and the link between education and economic growth (e.g., de la Croix \& Licandro, 1999; Schultz, 2004; Weir \& Knight, 2004), microeconomic approaches have been essentially calculating the rate of returns to education (Card, 1999, 2001; Mincer, 1974).

The present study aims at deepening the link between education and earnings and its differences across gender and across public versus private sector employment. The education premium is modelled relying on the framework of Mincer equation (Mincer, 1974). We test this model on a set of pseudo panel data developed out of the Employment Surveys by the Department of Statistics of Jordan from 2000 to 2015. Thus, this study contributes to the debate on returns to education, as well as to the literature on gender and public-private sector wage differentials.

Jordan is characterised by a good level of education: according to the World Bank, in 2012, school life expectancy in Jordan was 12.76 years, compared to 11.4 years in the low and middle income countries while gross enrolment rate in tertiary education was, in 2014, 45 percent vis-à-vis an average of 37 percent in the countries of the Middle East and North Africa (MENA). Nevertheless, unemployment among graduates is high and labour market participation rates are low, particularly among females. This makes Jordan an interesting case study to measure the returns to education. Furthermore, comparison of returns to education of male and female workers should also contribute to a better understanding of female participation rates.

Furthermore, even though Jordan has invested significant efforts in stimulating the private sector, the country is still characterised by a large public sector, which is employing a large share of the workforce. According to the Jordan Department of Statistics (DoS), in 2014, 38 percent of jobs was provided by the public sector. Considering the average share of workforce employed by the public sector between 2000 and 2010 across the countries of the MENA, Jordan ranked first with a share of 40.4 percent, followed by Saudi Arabia (37.9 percent), Palestine (32 percent), and Algeria (31 percent). Over the same period, public sector employment was 15.4 percent in Turkey and 14.6 percent in Morocco (data from Statista, 2016).

Among the main pillars of the economic reform process which started in Jordan in the aftermath of its financial crisis of 1989 were the privatisation of state owned enterprises and the reduction of the size of the public sector. Thus, the share of public sector employment has been progressively reduced. As a comparison, throughout the 1970 s and 1980s, it can be estimated that between 50 and 60 percent of job entrants found employment in the public sector (Assaad, 2014).

Still, preference toward public sector employment is very common in Jordan (Dougherty, 2010) and in the whole Middle East. As ascertained from Gallup's World Poll for 2012, preference for employment in the public sector in Jordan reached more than 65 percent among young adults (15-29 years) and surpassed 70 percent among 
people over 30 years. Besides conditions of employment (the public sector is more attractive in terms of job security, working hours and medical insurance (Dougherty, 2010)), different educational premiums may represent one of the possible reasons for this preference. Therefore, the present study also investigates and compares returns to education from public and private sector employment. We believe that the estimation of returns to education is very important to characterise the labour market of the country and understand some of its dynamics, as well as to better contextualise the demand for education.

The study is articulated as follows: Section 2 presents a critical overview of the literature on returns to education and wage differentials. Section 3 reviews some main features of Jordan concerning educational level and labour market characteristics. The empirical analysis is then discussed through presenting the theoretical framework and the econometric model (Section 4), data specification (Section 5) and estimation techniques and main results (Section 6). Section 7 concludes the study.

\section{Returns to Education}

The link between education and earnings has been deeply investigated in the literature and early contributions can be traced back to Friedman \& Kuznets (1954). Without any doubt, the debate has been dominated by the approach formulated by Mincer (1974); since then, despite of critiques and notwithstanding the formulation of alternative approaches, ${ }^{1}$ the most common way of estimating returns to education has often been the ordinary least squares (OLS) estimation of Mincer equation (Card, 1999, 2001).

The theoretical foundation of Mincer equation can be traced back to Becker's theories of rational households' decision making (Becker, 1964). In Becker's framework, wages are the remuneration for human capital and differences in wages can be explained by the heterogeneity of individuals. Thus, they reflect individual characteristics, such as ability, education and experience. The decision to invest into education emerges as the optimal solution to the inter-temporal weighing of costs and benefits of education (Becker, 1964).

In its simplest form, Mincer assumes the logarithm of wages to be a function of education and experience. The model assumes constant and homogeneous returns from education (proxied by the years of schooling) and experience (age minus the number of years of schooling) (Mincer, 1974). The main variations of this basic model have been essentially motivated by relaxing one assumption or more. Critiques and additions to Mincer equation can thus be classified into contributions pointing at: (1) the endogeneity of education, (2) the non linearity of the education premium, and (3) the heterogeneity of the experience premium.

First, Mincer equation posits education to be exogenous even though education is likely to be influenced by skills and ability which are heterogeneous characteristics of

\footnotetext{
1 For example, among the alternatives to Mincer equation there is the comparison of cost and benefits of education, as well as the so-called shortcut methods. For an overview, see Diagne and Diene (2011).
} 
individuals. Endogeneity of schooling (Heckmann, Lochner, \& Todd, 2003) and the socalled 'ability bias' (Harmon, Oosterbeek, \& Walker, 2003) have been taken into account including proxies for natural ability (such as school grades and intelligence quotient (IQ) grades, see Harmon, Oosterbeek, \& Walker, 2000), as well as different instrumental variables (e.g., distance to school, spouses' and/or parents' education and early stage smoking, see Lall and Sakellariou, 2010).

The discussion on the relevance of endogeneity of schooling and on how to take it into account is longstanding and has been of concern for numerous researchers (e.g., Card, 1995, 1999; Griliches, 1977; Heckman \& Vytlacil, 2003; Willis, 1986; Willis \& Rosen, 1979). Still, the debate is open and there are conflicting views on the topic.

Besides, several studies point at the fact that the relationship between wages and education is non linear per se and its non linearity is not only due to the heterogeneity of skills (Belzil, 2006; Belzil \& Hansen, 2002). Accepting this view means to question the instrumental variables (IV) approach to education in general; the underlying problem of IV is that in the case of education, all IV variables turn out to be in some ways correlated to socioeconomic indicators (Card, 1999; Heckman \& Urzua, 2009) that are, again, related both to education choices and to wages.

This issue is backed by the fact that IV estimates of the Mincer equation lead to a puzzling result: if the heterogeneity of skills represents a problem, the education premium estimated according to the IV approach (i.e., adding some control variables to control for heterogeneity) should be lower than when relying on a simple OLS estimation of the returns to education.

However, there is considerable evidence affirming that OLS estimates are lower than IV estimates (Blundell, Dearden, \& Sianesi, 2001; Harmon, Oosterbeek, \& Walker, 2000; Harmon et al., 2003; Lall \& Sakellariou, 2010; Maluccio, 1998). Card (2001) explained this paradox based on the fact that IV estimates marginal returns while OLS estimates average returns. But, evidence seems to contrast this view, as marginal returns from education tend to be lower than average returns (see Carneiro \& Heckman, 2002 and Carneiro, Heckman, \& Vytlacil, 2005, referring to a large sample of US college students).

A related line of analysis came to the conclusion that endogeneity of skills does not matter much in the end, as there are too many types of abilities and some of them may be even negatively correlated to schooling (Angrist \& Krueger, 1991).

The choice of control variables has been inspired by a vast literature investigating the importance of socioeconomic factors in determining wages: to provide some examples, Lam and Schoeni (1993) estimated that only the fact of having a father with a university degree leads to a 20 percent wage premium.

A further factor that is significantly influencing wages seems to be public versus private sector employment. Even though most of the studies have proven public sector to yield for higher returns (Mann \& Kapoor, 1988; Rees \& Shah, 1995), some analysts found evidence for negative premium of public employment (e.g., Lall \& Sakellariou, 2010 for Cambodia and Hyder, 2007 for Pakistan).

Studies comparing the returns to education of males and females provide consistent results that returns to education are higher among females (e.g., Bakis, Nurhan, Haluk, \& Sezgin, 2013; Dougherty, 2005; Trostel, Walker, \& Woolley, 2002). This finding 
relies on the common consideration of considering female educational attainment (in many countries lower than among males) and female participation rate.

Quality of schooling has also been mentioned as an important factor to be added to the analysis, but contributions face some difficulties in developing reliable proxies for the quality of education. Suggestions consisted in looking at the ratio of pupil to teacher and at the relative teacher's pay (Card \& Krueger, 1992), considering school expenditures per capita and the share of unqualified school teachers (Moll, 1992).

The second line of critique to the original Mincer equation questions the assumption of linearity of returns to education. Despite some support for linearity (Card \& Krueger, 1992), most of the studies corroborate the idea that premiums from education are convex (Belzil, 2006; Deschenes, 2001; Lemieux, 2003; Mincer, 1996). Convexity may be a result of the sheepskin effect. Non linearity of returns has been typically modelled regressing the coefficient for schooling squared (Diagne \& Diene, 2011; Heckman, Layne-Farrar, \& Todd, 1996; Lemieux, 2003).

The third issue with regard to Mincer's original model is heterogeneity of returns from experience. The assumption of constant returns from experience does not seem to hold, as different educational levels lead to different coefficients for experience (Heckman et al., 2003) and provide different growth profiles of wages. This result has been backed by numerous studies (Andini, 2008; Belzil, 2006; Card \& Lemieux, 2001).

In general, the type of data also matters for the model specification: as discussed by Heckmann et al. (2003), the 1960s US Census data used by Mincer for the original model specification were fitting the model's assumptions. However, the same assumptions are not always met by different datasets and it has been further demonstrated that returns to education crucially depend on the type of data used for estimation (among the studies finding differences between estimates based on cross sectional and cohort data are Katz \& Autor, 1999; Katz \& Murphy, 1992; Murphy \& Welch, 1992).

Arbak (2012) estimated returns to education by including (but not specifically targeting) the case of Jordan (as part of the Southern Mediterranean countries) resulted in demonstrating the returns to education to be lower in Jordan than in other countries of the region.

\section{Education and the Labour Market in Jordan}

The education sector in Jordan has witnessed a remarkable development during the past two decades, as the demand for education is very high. To meet this demand, numerous public and private schools and universities are operating in the country. It can be estimated that around 38 percent of the students are in private schools. The number of higher education institutions has also increased as a result of the sustained demand for higher education that is mainly seen as a key to enter the labour market whether in Jordan or abroad. According to the Ministry of Higher Education, there are 10 public and 18 private universities.

The latest census for the year 2015 assesses population in Jordan to be 9.5 million inhabitants ( 37 percent of which are below 15 years of age). In general, almost 33 percent of the total Jordanian population is enrolled in education ( 27 percent in 
schools and 5 percent in higher education institutions) (Department of Statistics of Jordan, DoS, 2015).

In 2016, the number of students enrolled at schools in Jordan (from primary to secondary level) was 1.9 million, almost equally split between male $(956,000)$ and female $(942,000)$ (DoS, 2016). In the same year, the number of students enrolled at higher education institutions was 276,000 and with a total of almost 143,000 , the share of females was almost 52 percent (DoS, 2016).

Comparing gross enrolment ratios in Jordan with averages for countries of the MENA region, it emerges that Jordan have a higher share of enrolment at both the secondary and tertiary education levels (Table 1 ).

According to the World Bank (2017) and adding to the evidence presented in Table 1 , the gross enrolment rate of females in tertiary education was 47 percent in 2015. This signalises a disparity in favour of females in higher education access and is corroborated by a Gender Parity Index at tertiary education level for the year 2015 of $1.11 .^{2}$

Table 1. Gross enrolment ratios in Jordan and the MENA region for 2014 (\%)

\begin{tabular}{lcc}
\hline Gross enrolment ratio (GER) & Jordan & MENA average \\
\hline Primary education & 97 & 105 \\
Secondary education & 82 & 79 \\
Tertiary (higher) education & 45 & 37 \\
\hline
\end{tabular}

Note: GER can exceed $100 \%$ due to the inclusion of over-aged and under-aged students because of early or late school entrance and grade repetition.

Source: World Bank (2017).

The Employment and Unemployment Survey of 2015 by DoS estimated 40 percent of the Jordanian adult population have achieved secondary education or more (Figure 1).

In 2015 , the Jordanian labour force consisted of 1.61 million individuals -1.32 million males and about 289,000 females (Ministry of Labor of Jordan, 2016). Despite the high demand for education, the share of economically active population in Jordan is among the lowest worldwide (World Bank, 2017). According to a survey by the DoS in 2015, the refined economic activity rate was around 36.7 percent (60 percent for males and 13.3 percent for females). Participation rate of females in the labour market is thus extremely low in Jordan and the gap between genders is sustained for all age groups.

In 2015, there were almost 1.4 million employed in Jordan, of which 84 percent were male and the remaining 16 percent female. The DoS survey for 2015 further

2 Gender Parity Index (GPI) is calculated as the ratio of female gross enrolment ratio for a certain level of education to the male gross enrolment ratio for the same level of education. If GPI equals 1, it means parity between females and males in access to education. A value less than 1 indicates disparity in favour of males, whereas a GPI greater than 1 indicates disparity in favour of females. 


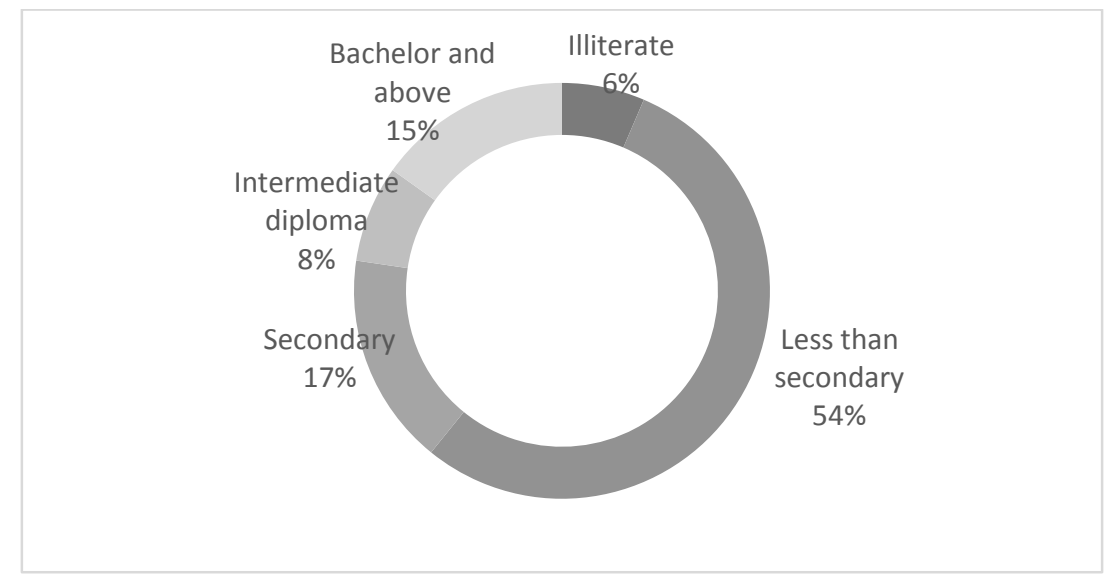

Figure 1. Jordanian adult population (15+) by educational level, 2015 Source: DoS, Employment survey, 2015.

revealed that accordingly with their educational level, employed Jordanians are almost equally split between those with less than secondary education (50.8 percent) and those above (48 percent) (Table 2). Specifically, around 26 percent of the employed Jordanian population has at least a bachelor's degree.

Hereby, it should be noted that the share of employed women with a bachelor's degree is more than double (58 percent) (Table 2). Despite the fact that there are more females than males in universities, labour market participation of females is low, due to socio-cultural and religious considerations (Clark, Ramsbey, \& Adler, 1991; Miles, 2002; Sidani, 2005; Spierings, Smits, \& Verloo, 2009). A similar trend is observable across most MENA countries and is labelled as the "gender equality paradox" (World Bank, 2013).

What has inspired our analysis is the direct comparison of average wages by educational level among males and females, as well as among public and private sector employees. The development of average monthly wages (in US\$) of males and of female

Table 2. Employed Jordanians by educational level, 2015

\begin{tabular}{lccc}
\hline $\begin{array}{l}\text { Employed by } \\
\text { educational level }\end{array}$ & $\begin{array}{c}\text { \% of overall } \\
\text { total }\end{array}$ & $\begin{array}{c}\text { \% out of } \\
\text { female respondents }\end{array}$ & $\begin{array}{c}\text { \% out of } \\
\text { male respondents }\end{array}$ \\
\hline Illiterate & 1.0 & 0.8 & 1.0 \\
Less than secondary & 50.8 & 13.4 & 57.6 \\
Secondary & 12.0 & 6.6 & 13.0 \\
Intermediate diploma & 10.0 & 20.9 & 8.1 \\
Bachelor degree & 26.1 & 58.3 & 20.3 \\
\hline Total & 99.9 & 100.0 & 100.0 \\
\hline
\end{tabular}

Source: DoS, Employment survey, 2015. 


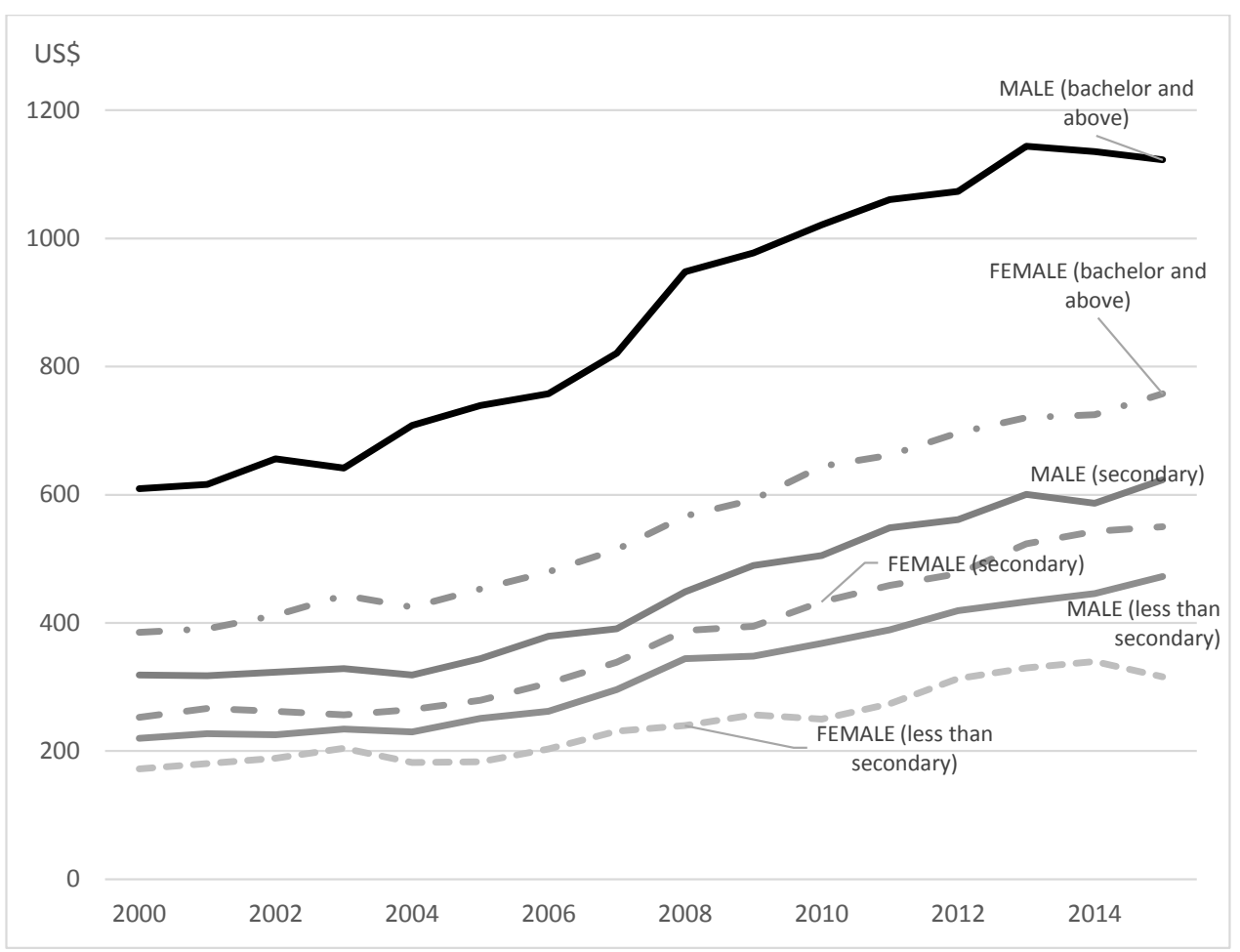

Figure 2. Average monthly wages of employees in Jordan by gender, 2000-2015 (US\$) Source: DoS, Employment surveys, 2001-2016.

employees by educational level is presented by Figure 2. Besides the clear gap in favour of male employees, the graph points at smaller education premiums among females.

An interesting trend has also emerged out of the comparison of wages in the private and public sector by gender: a clear public-private sector wage gap adds to the gender gap and to the lower educational premium of females that hold across sectors. Figure 3 presents the average monthly wages of employees by educational level, gender and private-public sector between 2010 and 2015. As it emerges, average male wages are higher than female wages for all levels of education while wages for both genders are higher in the public than in the private sector (with the exception of private sector wages for male bachelor graduates). A similar situation holds across the years, without any sign of alignment of public to private sector wages.

\section{Theoretical Framework}

In its basic formulation, Mincer equation models wages (in logarithm) as dependent on years of schooling and experience, as follows:

$$
\ln W=a+b S+c E+\varepsilon
$$

with $W$ representing wage, $S$, years of schooling, $E$, experience (typically modelled as the difference between present age minus years of schooling), and $\varepsilon$ the error term. 


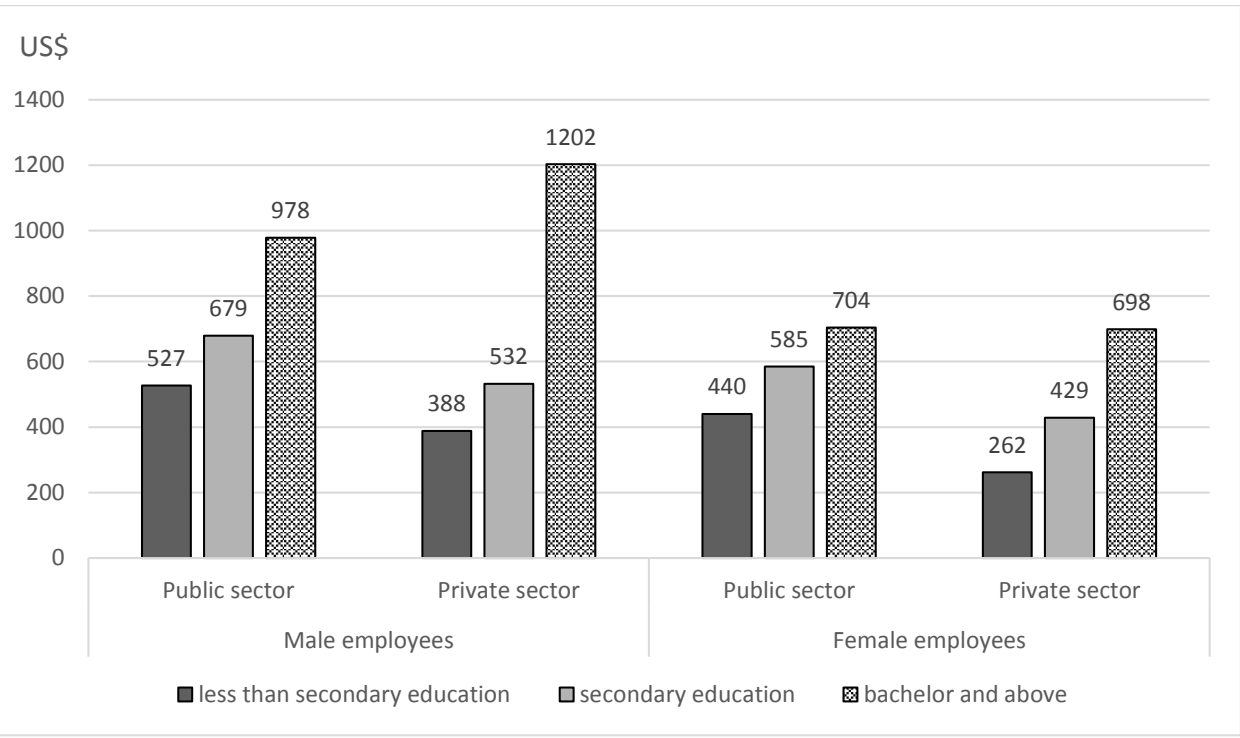

Figure 3. Average monthly wages by education, gender and public-private sector of employment, 2010-2015 (US\$)

Source: DoS, Employment surveys, 2010-2016.

In light of the debate and on the main critiques to the estimation of returns to education (see Section 2), this study considers a modified Mincer equation regressing the logarithm of wages on the years of schooling, i.e.

$$
\ln W=a+b S+\varepsilon
$$

Control variables are excluded to avoid endogeneity with education. In econometric terms, control variables should be treated as IV, whereas "the validity of a particular IV estimator depends crucially on the assumption that the instruments are uncorrelated with other latent characteristics of individuals that may affect their earnings" (Card, 2001, p. 1143). Thus, from a theoretical point of view, the addition of control variables to capture the returns to education is per se critical. This is confirmed by previous findings revealing that IV estimations tend to provide higher estimation of the returns to education than the basic OLS.

Experience is not directly encompassed in the estimated model, but we indirectly take experience into account by randomising it: we refer to independent cross section data with cohorts being three different educational levels (pre-secondary, secondary, bachelor and more). Each cohort is built out of large scale annual surveys by the DoS looking at a random sample of the adult population. Given the large size of each cohort, we expect age and experience to be randomised. In addition, relying on large cohorts, we can reasonably assume that the distribution of skills and ability is the same within each cohort.

To investigate two important aspects of the labour market in Jordan (that is gender bias and wage premium in the public sector), the cohorts will be further disaggregated 
by gender and by public versus private sector employment. The differences between these groups of individuals are analysed to compare returns to education between males and females, as well as within private and public sector employees.

Accordingly, we estimate three variations of the Mincer equation: the first variation estimates the returns to education for the entire sample, considering a dummy variable for gender where 0 is for males and 1 for females, to capture the differences in education premium by gender.

The second model focuses on male employees, adding a dummy for private-public sector employment, where 0 stands for public and 1 for private sector.

The third model considers female employees, with a dummy for private-public sector employment ( 0 for public and 1 for private sector).

\section{Data Specification}

The analysis is based on data from the Employment Survey by the DoS. This survey is run over a large scale representative sample of all public and private sector establishments of the country. It is run on a yearly basis and conforms to international standards and definitions. Data from this survey are independent repeated cross sections, as they are collected over different individuals. Our analysis considers the period between 2000 and 2015.

Actually, surveys generating genuine panel data are missing in many countries (Verbeek, 2008). Therefore, it is pretty common to have to rely on repeated cross sections to generate a set of pseudo panel data. The underlying idea in analysing repeated cross sections is to group data into cohorts and consider averages within these cohorts as observation in a (pseudo) panel data setting (Deaton, 1985).

Due to the size of the sample and to its randomisation, we can treat the repeated cross sections from the Employment Surveys as pseudo panel data. Data have thus been divided into three cohorts, based on the educational level. We herewith obtain three (mutually exclusive and collectively exhaustive) groups including individuals with less than secondary education (i.e., between 0 and 11 years of schooling), with secondary education and intermediate diploma (i.e., from 12 to 15 years of schooling), and with bachelor degree and above (i.e., more than 16 years of education). The variables considered are wages in Jordanian Dinar (JD) ${ }^{3}$ in logarithmic form to be regressed against educational level.

\section{Econometric Analysis and Results}

In general, there are three main models that can be applied with panel data: pooled models, fixed effects models and random effects models. The choice between the different models depends on the characteristics of the data (for more, see Greene, 2012). Thus, to determine which model is more appropriate, a pairwise comparison of the different models and specific tests should be done. Specifically, the F-test compares

3 JD is pegged to the US dollar with a rate of JD1 = USD1.41044. 
the fit of pooled versus fixed effects models, the Lagrange Multiplier (LM) compares pooled versus random effects models, while the Haussman test compares fixed to random effects models.

For the present analysis, the redundant fixed effect test has revealed for all of the three variations of the model that fixed effects models are the appropriate choice. ${ }^{4}$ Random effects models do not suit our data, as educational level is time invariant (Park, 2011).

The results from the estimation of the three cohorts presented in Section 5 by mean of fixed effects models are as shown in Table 3.

All of the coefficients for the estimated regressions are significant at 1 percent level and the adjusted $\mathrm{R}^{2}$ are $0.94,0.85$ and 0.88 respectively. In general, the results from estimation (1) indicate that returns to education in Jordan are approximately 6.7 percent, i.e., one additional year of schooling for an employee in Jordan averagely increases wage by 6.7 percent. This result is in tune with previous studies assessing that returns to education typically vary between 2 to 10 percent (e.g., Harmon et al., 2000).

In estimation (1), the negative sign for the coefficient of the dummy variable indicates that female wages are less than male wages. To determine the ratio of female average wage to male average wage, we have substituted the years of schooling and the values of the dummy variable in the estimated equation. Taking the exponential value of this result for males and for females (thus solving the equation by wage), we

Table 3. Results of econometric estimations

\begin{tabular}{|c|c|c|c|}
\hline & Estimation 1 & Estimation 2 & Estimation 3 \\
\hline Dependent variable & $\ln (W)$ & $\ln (\mathrm{WM})$ & $\ln (W F)$ \\
\hline Constant & $\begin{array}{r}4.997083^{* * *} \\
\text { SE } 0.032385 \\
\text { t-Stat } 154.3039\end{array}$ & $\begin{array}{r}5.062690 * * * \\
\text { SE } 0.052359 \\
\text { t-Stat } 96.69122\end{array}$ & $\begin{array}{r}5.026044 * * * \\
S E 0.041993 \\
t \text {-Stat } 119.6867\end{array}$ \\
\hline Schooling & $\begin{array}{r}0.066563^{* * *} \\
S E 0.002174 \\
\text { t-Stat } 30.61694\end{array}$ & $\begin{array}{r}0.068254^{* * *} \\
S E 0.003515 \\
\text { t-Stat } 19.41785\end{array}$ & $\begin{array}{r}0.054532 * * * \\
\text { SE } 0.002819 \\
t \text {-Stat } 19.34350\end{array}$ \\
\hline $\begin{array}{l}\text { Dummy gender } \\
\text { (0=Male; } 1=\text { Female) }\end{array}$ & $\begin{array}{r}-0.305115^{* * *} \\
\text { SE } 0.024101 \\
\text { t-Stat }-12.66004\end{array}$ & & \\
\hline $\begin{array}{l}\text { Dummy sector } \\
\text { (0=Public; } 1=\text { Private sector) }\end{array}$ & & $\begin{array}{r}-0.106122^{* * *} \\
\text { SE } 0.038966 \\
\text { t-Stat }-2.723480\end{array}$ & $\begin{array}{r}-0.298236 * * * \\
S E 0.031251 \\
t-S t a t-9.543146\end{array}$ \\
\hline $\mathrm{R}^{2}$ & 0.9512 & 0.8763 & 0.9038 \\
\hline Adj. $R^{2}$ & 0.9406 & 0.8493 & 0.8829 \\
\hline F-statistic & $28.27 * * *$ & $11.22 * * *$ & $17.88 * * *$ \\
\hline
\end{tabular}

Note: ${ }^{* * *}$ significant at $1 \%$. WM and WF refer to male wages and female wages, respectively.

4 For the econometric analysis, the software EViews has been used. 
can then calculate the ratio of the average wage of females to males. We present the calculation for one year of schooling as follows:

$$
\begin{aligned}
& \ln (W)=4.997+0.067(1)-0.305(0)=5.064 \quad \Rightarrow \quad e^{5.064}=158.222 \\
& \ln (W)=4.997+0.067(1)-0.305(1)=4.759 \quad \Rightarrow \quad e^{4.759}=116.629
\end{aligned}
$$

Dividing the wage of females by the wage of males for one year of education, we obtain the ratio of female to male wages:

$$
\frac{116.629}{158.222}=0.737 \approx 74 \%
$$

This ratio means that, on average, female employees earn approximately 74 percent of their male colleagues. This calculation yields the same ratio for every number of years of schooling.

The second estimation shows that the return to education for males is 6.8 percent and that male wages in the private sector are inferior to those in the public sector. Specifically, males working in the private sector in Jordan earn around 90 percent of males employed by the public sector.

The third estimation further supports the view that the returns to education for females are inferior to males. Specifically, one additional year of schooling for females increases their average wage by around 5.5 percent. From solving the wage equation by inserting the years of schooling and the dummy, the results further show that females in the private sector earn 26 percent less than those in the public sector.

Overall, the main results from this study are that wages in the public sector are higher than those in the private sector. This confirms the results of previous studies (Dougherty, 2010) and points at the fact that despite the reform efforts to enhance the private sector and to align public and private sector wages (MOPIC, 2014), the public sector is still more attractive for the labour force in Jordan.

A second major result is that female workers seem to be disadvantaged by the labour market. Despite their high educational level, females' participation in the labour market is still very limited and their earnings are lower. The authorities seem to be aware of the gender bias with the wages and since 2010 Jordan has been actively cooperating with the International Labour Organization to promote wage equity across genders.

\section{Conclusion}

The present study adds to the existing literature on the link between education and earnings, focusing on the case of Jordan. It compares the education premiums of males and females, as well as of public and private sector employees by means of a simplified Mincer equation.

The analysis reveals that the wage premium from one additional year of schooling is 6.8 percent for males and 5.5 percent for females. Actually, for most of the countries, 
returns to education seem to be higher among females (Harmon et al., 2000; Lauer, 2004) and there is further evidence showing that the gap between male and female returns to education is larger in the countries with lower female participation in the labour market (Harmon et al., 2000). We believe that our results should be associated with the peculiarities of the Jordanian labour market which is characterised by an extremely low participation rate of females and high unemployment rates, notwithstanding females' high education profile. ${ }^{5}$ This result corroborates evidence on the so-called "gender equality paradox", which is widespread in the MENA region and points at the dicrepancy between a substantial gender equity in access to education visà-vis low participation rates of females (World Bank, 2013).

Female participation in the labour market is influenced by social, cultural and religious factors dealing with the role of women in society and with the centrality of the family. In particular, religion and tradition (Hayo and Caris, 2013) as well as the persistence of a patriarchal culture (Sidani, 2005) seem to play a decisive role in constraining the participation of females in the labour market.

Further, several studies corroborate the link between female education and participation rate and public sector employment (Assaad \& El-Hamidi, 2009; Assaad, Hendy, \& Yassine, 2014). The main idea is that, due to cultural and religious reasons, female participation in the labour market is in many cases restricted to public sector job opportunities (that represent a symbol of status and an acceptable job for females). Cultural and social norms not only play a role in the choice of what is perceived to be an acceptable job for a female, but also in restricting their mobility.

The findings related to the wage differential between private and public sector employees by education show that private sector wages are 90 percent of the public sector wages for male employees and only 74 percent of the public sector wages for female employees.

There are several studies providing worldwide evidence to explain the wage gap in favour of the public sector (for a review, see Campos, Depalo, Papapetrou, Perez, \& Ramos, 2017) and for Jordan, a seminar report has been dedicated to monetary and non monetary differences between the private and public sector (Dougherty, 2010). The authorities are aware of this gap and, above all else, a central objective of Jordan's National Employment Strategy 2011-2020 (MOPIC, 2014) is linked to the alignment of wages between the two sectors.

\section{References}

Andini, C. (2008). The dynamic Mincer equation: Evidence and theory (Working Paper), Funchal, Portugal: Universidade da Madeira.

Angrist, J.D., \& Krueger, A.B. (1991). Does compulsory schooling attendance affect schooling and earnings. The Quarterly Journal of Economics, 106(4), 979-1014. doi: 10.2307/2937954

Arbak, E. (2012). Measuring returns to education and human capital in the southern Mediterranean (MEDPRO Technical Report No. 17). Brussels, Belgium: European Commission.

5 For a regional comparison of equality in education opportunity, see Salehi-Isfahani, Hassine, and Assaad (2014). 
Assaad, R., \& El-Hamidi, F. (2009). Women in the Egyptian labor market: An analysis of developments, 1988-2006. In R. Assaad (Ed.), The Egyptian labor market revisited (pp. 219258). Cairo: American University in Cairo Press.

Assaad, R. (2014). Making sense of Arab labor markets: The enduring legacy of dualism. IZA Journal of Labor \& Development, 3(6), 1-25. doi: 10.1186/2193-9020-3-6

Assaad, R., Hendy, R., \& Yassine, C. (2014). Gender and the Jordanian labor market. In R. Assaad (Ed.), The Jordanian labor market in the new millennium (Chapter 4). Oxford: Oxford University Press. doi: 10.1093/acprof:oso/9780198702054.003.0004

Bakis, O., Nurhan, D., Haluk, L., \& Sezgin, P. (2013). Quantile estimates for social returns to education in Turkey: 2006-2009. Middle East Development Journal, 5(3), 1350017-1-1350017-23. doi: $10.1142 / S 179381201350017 X$

Barro, R.J. (1991). Economic growth in a cross-section of countries. The Quarterly Journal of Economics, 106(2): 407-443. https://doi.org/10.2307/2937943

Becker, G.S. (1964). Human capital: A theoretical and empirical analysis with special reference to education. Chicago: University of Chicago Press.

Belzil, C. (2006). Testing the specification of the Mincer wage equation (GATE Working Paper Series No. 06-08). Ecully, France: GATE UMR 5824 du CNRS.

Belzil, C., \& Hansen, J. (2002). Unobserved ability and the return to schooling. Econometrica, 70(5), 2075-2091. https://doi.org/10.1111/1468-0262.00365

Blundell, R., Dearden, L., \& Sianesi, B. (2001). Estimating the returns to education: Models, methods and results. London: Centre for the Economics of Education, London School of Economics.

Campos, M.M., Depalo, D., Papapetrou, E., Perez, J.J., \& Ramos, R. (2017). Understanding the public sector pay gap. IZA Journal of Labor Policy, 6(7), 1-29. doi: 10.1186/s40173-0170086-0

Card, D. (1995). Earnings, schooling, and ability revisited. In S. Polachek (Ed.), Research in labor economics, 14 (pp. 23-48). Greenwich, CT: JAI Press.

Card, D. (1999). The causal effect of education on earnings. In D. Card \& O. Ashenfelter (Eds.), Handbook of labor economics, volume 3 (pp. 1801-1863). Amsterdam: Elsevier.

Card, D. (2001). Estimating the return to schooling: Progress on some persistent econometric problems. Econometrica, 69(5), 1127-1160. doi: 10.1111/1468-0262.00237

Card, D., \& Krueger, A.B. (1992). Does school quality matter? Returns to education and the characteristics of public schools in the United States. Journal of Political Economy, 100(1), 1-40.

Card, D., \& Lemieux, T. (2001). Can falling supply explain the rising return to college for younger men? A cohort-based analysis. The Quarterly Journal of Economics, 116(2), 705-746. https:// doi.org/10.1162/00335530151144140

Carneiro, P., \& Heckman, J. (2002). The evidence on credit constraints in post-secondary schooling. Economic Journal, 112(October), 989-1018.

Carneiro, P., Heckman, J., \& Vytlacil, E. (2005). Understanding what instrumental variables estimate: Estimating marginal and average returns to education (Working Paper, Econ 350). Chicago, IL: University of Chicago.

Clark, R., Ramsbey, T., \& Adler, E. (1991). Culture, gender and labor force participation: A crossnational study. Gender \& Society, 5(1): 47-66.

de la Croix, D., \& Licandro, O. (1999). Life expectancy and endogenous growth. Economic Letters, 65(2) 255-263. https://doi.org/10.1016/S0165-1765(99)00139-1

Deaton, A. (1985). Panel data from time-series of cross-sections. Journal of Econometrics, 30(1-2), 109-126. https://doi.org/10.1016/0304-4076(85)90134-4

Department of Statistics (DoS), Jordan. (various years). Employment and unemployment survey. Amman, Jordan: Author.

Department of Statistics (DoS), Jordan. (various years). Jordan in Figures. Amman, Jordan: Author. 
Deschenes, O. (2001). Unobserved ability, comparative advantage and the rising return to education in the United States: A cohort-based approach (Industrial Relations Section Working Paper No. 465). Princeton, NJ: Princeton University.

Diagne, A., \& Diene, B. (2011). Estimating returns to higher education: A survey of models, methods and empirical evidence. Journal of African Economies, 20(AERC Supplement 3), iii80-iii132. doi: 10.1093/jae/ejr021

Dougherty, C. (2005). Why are returns to schooling higher for women than for men? The Journal of Human Resources, 40(4): 969-988.

Dougherty, C. (2010). A comparison of public and private sector earnings in Jordan (Conditions of Work and Employment Series No. 24). Geneva, Switzerland: International Labour Organization.

Friedman, M., \& Kuznets, S. (1954). Income from independent professional practice. Cambridge, MA: National Bureau of Economic Research (NBER).

Greene, W.H. (2012). Econometric Analysis (7th ed.) Essex, England: Pearson Education Limited.

Griliches, Z. (1977). Estimating the returns to schooling: Some econometric problems. Econometrica, 45(1), 1-22. doi: 0012-9682(197701)45:1<1:ETRTSS>2.0.CO;2-2

Harmon, C., Oosterbeek, H., \& Walker, I. (2000). The returns to education: A review of evidence, issues and deficiencies in the literature. London: Centre for the Economics of Education, London School of Economics.

Harmon, C., Oosterbeek, H., \& Walker, I. (2003). The returns to education: Microeconomics. Journal of Economic Surveys, 17(2), 115-156. doi: 10.1111/1467-6419.00191

Hayo, B., \& Caris, T. (2013). Female labour force participation in the MENA region: The role of identity. Review of Middle East Economics and Finance, 9(3), 271-292. doi: 10.1515/ rmeef-2013-0021

Heckman, J., \& Vytlacil, E. (2003). Econometric evaluation of social programs. In J.J. Heckman \& E. Leamer (Eds.), Handbook of econometrics, vol. 6. Amsterdam: North-Holland.

Heckman, J.J., Layne-Farrar, A., \& Todd, P.E. (1996). Human capital pricing equations with an application to estimating the effect of schooling quality on earnings. The Review of Economics and Statistics, 78(4), 562-610. doi: 10.2307/2109948

Heckman, J.J., Lochner, L.J., \& Todd, P.E. (2003). Fifty years of Mincer earnings regressions (NBER Working Paper No. 9732). Cambridge, MA: National Bureau of Economic Research. doi: 10.3386/w9732

Heckman, J.J., \& Urzua, S. (2009). Comparing IV with structural models: What simple IV can and cannot identify (NBER Working Paper No. 14706). Cambridge, MA: National Bureau of Economic Research. doi: 10.3386/w14706

Hyder, A. (2007). Preference for public sector jobs and wait unemployment: A micro data analysis (PIDE-Working Papers, 2007:20). Islamabad, Pakistan: Pakistan Institute of Development Economics.

Katz, L., \& Murphy, K. (1992). Changes in relative wages, 1963-1987: Supply and demand factors. The Quarterly Journal of Economics, 107(1), 35-78. doi: 10.2307/2118323

Katz, L.F., \& Autor, D.H. (1999). Changes in the wage structure and earnings inequality. In O. Ashenfelter \& D. Card (Eds.), Handbook of labor economics, vol. 3A (pp. 1463-1555) (Handbooks in economics, vol. 5). Amsterdam, Netherlands: Elsevier Science, North-Holland.

Lall, A., \& Sakellariou, C. (2010). Evolution of education premiums in Cambodia: 1997-2007. Asian Economic Journal, 24(4), 333-354. doi: 10.1111/j.1467-8381.2010.02044.x

Lam, D., \& Schoeni, R. (1993). Effects of family background on earnings and returns to schooling: Evidence from Brazil. Journal of Political Economy, 101(4), 710-740.

Lauer, C. (2004). Education, gender and earnings in France and Germany: Level and dispersion effects (Discussion Paper No. 04-54). Mannheim, Germany: Zentrum für Europäische Wirtschaftsforschung (ZEW). 
Lemieux, T. (2003). The "Mincer equation" thirty years after Schooling, experience and earnings (Center for Labor Economics Working Paper No. 62). Berkeley, CA: University of California. Retrieved from http://emlab.berkeley.edu/users/cle/wp/wp62.pdf

Maluccio, J. (1998). Endogeneity of schooling in the wage function: Evidence from the rural Philippines (FCND Discussion Paper No. 54). Washington D.C.: International Food Policy Research Institute. Retrieved from http://www.ifpri.cgiar.org/sites/default/files/publications/dp54.pdf

Mann, P., \& Kapoor, B. (1988). Earnings differentials between public, private and joint sectors in Punjab (India). The Journal of Development Studies, 25(1), 97-111. doi: 10.1080/ 00220388808422097

Miles, R. (2002). Employment and unemployment in Jordan: The importance of the gender system. World Development, 30(3): 413-427. doi: 10.1016/S0305-750X(01)00123-1

Mincer, J. (1974). Schooling, experience and earnings. Cambridge, MA: National Bureau of Economic Research (NBER).

Mincer, J. (1996). Changes in wage inequality, 1970-1990. (NBER Working Paper No. 5823). Washington DC: National Bureau of Economic Research. doi: 10.3386/w5823

Ministry of Labor of Jordan. (2016). Labor market in Jordan in figures, 2016. Amman, Jordan: Author.

Ministry of Planning and International Cooperation (MOPIC), Jordan. (2014). Jordan's national employment strategy 2011-2020. Jordan: Author.

Moll, P.G. (1992). Quality of education and the rise in returns to schooling in South Africa, 19751985. Economics of Education Review, 11(1), 1-10. doi: 10.1016/0272-7757(92)90016-V

Murphy, K.M., \& Welch, F. (1992). The structure of wages. The Quarterly Journal of Economics, 107(1): 285-326. doi: 10.2307/2118330

Park, H.M. (2011). Practical guides to panel data modeling: A step-by-step analysis using Stata (Tutorial Working Paper). Niigata, Japan: Graduate School of International Relations, International University of Japan.

Rees, H., \& Shah, A. (1995). Public-private sector wage differential in the UK. The Manchestor School, 63(1), 52-68. https://doi.org/10.1111/j.1467-9957.1995.tb00268.x

Salehi-Isfahani, D., Hassine, N.B., \& Assaad, R. (2014). Equality of opportunity in educational achievement in the Middle East and North Africa. Journal of Economic Inequality, 12(4): 489515. doi: 10.1007/s10888-013-9263-6

Schultz, T.P. (2004). School subsidies for the poor: Evaluating the Mexican Progresa poverty program. Journal of Development Economics, 74(1), 199-250. doi: 10.1016/j.jdeveco.2003. 12.009

Sidani, Y. (2005). Women, work, and Islam in Arab societies. Women in Management Review, 20(7), 498-512. doi: 10.1108/09649420510624738

Spierings, N., Smits, J., \& Verloo, N. (2009). On the compatibility of Islam and gender equality: Effects of modernization, state Islamization, and democracy on women's labor market participation in 45 Muslim countries. Social Indicators Research, 90(3), 503-522. doi: 10.1007/ s11205-008-9274-z

Statista. (2016). Retrieved from www.statista.com

Trostel, P., Walker, I., \& Woolley, P. (2002). Estimates of the economic return to schooling for 28 countries. Labour Economics, 9(1), 1-16. doi: 10.1016/S0927-5371(01)00052-5

Verbeek, M. (2008). Pseudo-panels and repeated cross-sections. In L. Matyas \& P. Sevestre (Eds.), The Econometrics of panel data: Fundamentals and recent developments in theory and practice (pp. 369-383). Berlin/Heidelberg, Germany: Springer-Verlag GmbH.

Weir, S., \& Knight, J. (2004). Externality effects of education: Dynamics of the adoption and diffusion of an innovation in rural Ethiopia. Economic Development and Cultural Change, 53(1), 93-113, doi: 10.1086/423254 
Willis, R.J. (1986). Wage determinants: A survey and reinterpretation of human capital earnings function. In O.C. Ashenfelter \& R. Layard (Eds.), Handbook of Labor Economics 1 (pp. 525602). Amsterdam: Elsevier/North-Holland. doi: 10.1016/S1573-4463(86)01013-1

Willis, R.J., \& Rosen, S. (1979). Education and self-selection. Journal of Political Economy, 87(5), S7-S36.

World Bank. (2013). Jobs for shared prosperity: Time for action in the Middle East and North Africa. Washington D.C.: Author.

World Bank. (2017). Education statistics (EdStats). Retrieved from http://datatopics.worldbank. org/education/ 
